\title{
OS DISCURSOS DAS TORCIDAS E DOS TERREIROS
}

\author{
Jonatas ELIAKIM (PUC/SP)
}

Este trabalho é parte de uma pesquisa de mestrado que tem por objetivo examinar a construção do herói moderno em discursos de terreiros e de torcidas de futebol. Nesse sentido, propomos identificar, nos gêneros de discurso ponto de umbanda e grito de torcida, os modos de organização e de inscrição dos sujeitos na cenografia e verificar o estatuto genérico dos discursos selecionados. $\mathrm{O}$ ethos que emerge nos discursos de grupos sociais relaciona-se com o conjunto de valores e princípios defendidos por identidades socioculturais. Esse aspecto mobiliza a pesquisa sobre a organização dos gêneros de discurso enunciados por alguns grupos identitários para compreender quais são, neles, as regularidades que nos permitem verificar os efeitos de sentido do surgimento de tal ethos discursivo e em que medida essa instância apresenta os aspectos políticos, sociais, ideológicos e culturais do homem brasileiro. Para nosso estudo, tomamos como referencial teórico-metodológico a Análise do Discurso, em especial, a praticada por Dominique Maingueneau (1997; 2000; 2001; 2004; 2007; 2008a; 2008b; 2009; 2010; 2015; 2016). O corpus, composto por dois cantos icônicos - um pertencente ao hinário dos fiéis do Templo Guaracy do Brasil e, outro, da torcida do São Paulo Futebol Clube - nos permitem identificar as regularidades pretendidas e apresentar a construção o laço de pertencimento identitário necessário para que a figura do representante do grupo, o herói, seja constituída.

Palavras-chave: Análise do Discurso; Gêneros de discurso; Pontos de umbanda; Gritos de torcida 